Portland State University

PDXScholar

\title{
An Analysis of Green Infrastructure Implementation Strategies in Portland and Other Global Leaders in Climate Action
}

Rachel L.R. LeMont

Portland State University

Follow this and additional works at: https://pdxscholar.library.pdx.edu/honorstheses

Part of the Environmental Monitoring Commons, and the Sustainability Commons Let us know how access to this document benefits you.

\section{Recommended Citation}

LeMont, Rachel L.R., "An Analysis of Green Infrastructure Implementation Strategies in Portland and Other Global Leaders in Climate Action" (2018). University Honors Theses. Paper 576.

https://doi.org/10.15760/honors.584

This Thesis is brought to you for free and open access. It has been accepted for inclusion in University Honors Theses by an authorized administrator of PDXScholar. Please contact us if we can make this document more accessible: pdxscholar@pdx.edu. 


\title{
An analysis of green infrastructure implementation strategies in Portland and other global leaders in climate action
}

\begin{abstract}
Green infrastructure has become increasingly popular as a way to mitigate and adapt to the effects of climate change in urban environments. Cities all over the world, including Portland, have developed their own strategies which inform local organizations on the actions they should take to be climate resilient - and many of these strategies include the implementation of green infrastructure. This thesis compares Portland's green infrastructure implementation strategies to those known around the world, and utilizes themes found in those strategies to create a survey on local green infrastructure initiatives in the Portland area. This information will be important for conservationists to exchange information on innovative approaches to climate change adaptation that are being taken, and identify areas where more focus is needed in the future.
\end{abstract}

\section{Introduction}

While many believe that climate change is a problem for the future, with $71 \%$ of Americans calling it a distant threat for future generations and 13\% saying it's not happening at all (Leiserowitz 2017), scientific evidence has shown that this global shift in environmental conditions is very much a current challenge for everyone. According to NASA, earth's average surface temperature has been increasing every year, global sea levels are rising, extreme weather events are occurring more frequently, our oceans are acidifying... and the list goes on (Callery 2017). The Intergovernmental Panel on Climate Change (IPCC) reported that the impacts and risks associated with climate change are even more severe than previously thought, and between 
2050 and 2100 climate change could cause detrimental effects to economies, security, development, and social systems. They also have strong evidence that humans are a major influence on the changes that are occurring, with cities being responsible for over $70 \%$ of global $\mathrm{CO} 2$ emissions. They speculate that if we continue to emit $\mathrm{CO} 2$ at current rates there will be further warming and long-lasting changes to our climate system for decades to come - which will have major effects on our sensitive natural and human systems (IPCC 2014).

The impacts of climate change will be especially apparent in urban areas due to aspects of the built environment, such as the urban heat island effect. The urban heat island results from higher concentrations of buildings and paved surfaces in the urban environment, which retain heat and inhibit cooling. In one heat wave that swept through Europe in 2003, more than 70,000 people died - and cities all over the world are starting to see increases in nighttime heat waves and heat related illness (The Impact of Climate Change on Cities N.d.). But while heat waves and the urban heat island are major problems cities are facing, there are several other impacts being seen such as rising sea levels, extreme flooding and erosion, changes to hydrological processes such as an increased rate and volume of surface runoff of rainwater (Gill 2007), increasing storm surges, decreased air and water quality, and changes to biodiversity (Wilby 2007).

Such cities have recognized these global issues and have developed collaborations with other cities in order to share strategies towards sustainable action on climate change. One such coalition is the C40 Cities Climate Leadership Group, which connects more than 90 cities, 650 million people, and one quarter of the global economy. This network of the worlds city officials, created and run by cities, has committed to addressing climate change through sharing knowledge and driving climate action (C40 2018). These cities have created their own climate 
action strategies, many of which recognize the benefits of green infrastructure (GI) as a way to adapt to the effects of climate change through carbon sequestration, increased shade and cooling, stormwater management, increased biodiversity, and much more spanning environmental, social, and economic domains. The use of GI for climate resiliency is further supported by the United States Environmental Protection Agency as a way to prepare for drought, manage flooding, reduce the urban heat island, lower building energy demands, spend less money managing water, and protect coastal areas (EPA 2016), and the European Commission has even created a Green Infrastructure and Climate Adaptation Strategy to promote the development of GI across the entire European Union - calling it the most widely applicable, economically viable, and effective tool to combat climate change and help adapt to or mitigate the adverse effects caused by climate change (European Commission n.d.).

A facilitated discussion at the 2017 Urban Ecosystem Research Consortium Symposium in Portland, Oregon (UERC 2017) with local conservationists, from organizations such as the Intertwine Alliance and the Oregon Department of Fish and Wildlife, identified interest in learning about innovative projects related to GI that local stakeholders are implementing, what their primary motivations are for doing so, approaches they are taking, and what strategies / plans they are utilizing to inform their projects. Given the potential impact climate change could have on urban areas coupled with the increasing popularity of GI implementation not only in Portland but also globally, this study addresses the following research questions: 1) how do strategies for addressing climate change through GI projects in Portland compare to those in other cities? 2) To what extent is climate change a factor in motivating GI projects in Portland?, and 3) What strategies or plans are being referenced in the design of these Portland projects? In order to address these questions, I will 1) compare the GI strategies from selected cities around 
the world to Portland's strategies, and 2) utilize these comparisons to create a survey tool for gathering information from local stakeholders about their GI implementation initiatives and motivations. This information will be important for conservationists to exchange information on innovative approaches to climate change adaptation that are being taken, and identify areas where more focus is needed in the future.

\section{Methods}

\section{$\underline{\text { Document Analysis }}$}

In order to determine if Portland's GI initiatives are consistent with those of cities around the world, I analyzed the climate action, GI, and biodiversity strategies of a sample of cities and compared / contrasted them to Portland's Climate Action Plan and Regional Conservation Strategy. I selected the cities, Barcelona, Melbourne, Singapore, Johannesburg, Rio de Janeiro, and Portland, based on their involvement with the C40 Cities Climate Leadership Group, their distribution around the world (one from each continent, excluding Antarctica), and the availability of their strategies.

While analyzing the strategies I identified their definitions of GI and what they consider the benefits to be, the climate change related risks they are trying to mitigate or adapt to, the broad strategies they have in place for each risk, and the specific types of GI they are implementing throughout each strategy. I then did a comparison of the synergies and gaps in GI implementation in Portland vs. around the world, and checked in on Portland's GI progress so far. 


\section{$\underline{\text { Survey }}$}

In order to compile the survey, I first identified the questions and concepts that I wanted to address. Such questions included 1) what types of conservation actions are organizations implementing related to GI? 2) what are their primary motivations for these actions (biodiversity, climate change, etc)? and 3) what broader strategies are these organizations referencing when developing their actions? I then developed questions that would yield appropriate responses. For example, I utilized the list of the most commonly implemented GI strategies found while analyzing the world's GI plans (see Appendix A) to allow people to select the strategy that their project most correlates with. This will inform the synergies and gaps in GI implementation during future analysis. Furthermore, my advisors and I met with local conservationists to determine what questions conservationists in Portland were interested in learning more about and that could be answered by this survey.

\section{Results}

\section{$\underline{\text { Document analysis }}$}

As previously mentioned, the cities selected for this analysis were Barcelona (Europe), Johannesburg (Africa), Singapore (Asia), Rio de Janeiro (South America), Melbourne (Australia), and Portland (North America) - representing very different climates and related struggles. Each of these cities have their own climate action strategies which emphasize the importance of nature in cities, and each of these climate strategies links to either a biodiversity plan or a green infrastructure plan. It was in these plans where the majority of green infrastructure related initiatives could be found and analyzed. These results will first introduce the strategies for each city by discussing what green infrastructure means to them. I will then 
start the comparisons between Portland and other cities with subjects such as climate risks, strategies to address these risks, and types of GI implemented in each strategy.

\section{City strategy introductions}

Barcelona has several plans related to climate change and sustainability, such as Barcelona, a city committed to the environment, which refers to GI as a "lung for the city" (City of Barcelona 2013, p.19), and The energy, climate change, and air quality plan of Barcelona describes GI as a way to decrease energy and mitigate the urban heat island effect (City of Barcelona 2011). Both of these climate plans have several sections devoted to urban biodiversity, and both reference the Barcelona green infrastructure and biodiversity plan 2020. This plan acts as a strategic instrument for long term actions that are needed to attain GI that can serve a number of environmental functions, with the main goal being to create a more fertile and resilient city in order to face up to "the very pressures and challenges it exerts" (City of Barcelona 2013).

\section{Melbourne's City of Melbourne Climate Change Adaptation Strategy says that the} adaptations that will be the most successful are those that minimize the vulnerability of the city to climate change. To do this, they have devoted almost their entire climate change strategy to moving the city of Melbourne towards an urban ecosystem, where natural systems are carefully integrated into the built environment, rather than them being completely separate (City of Melbourne 2008). This document references the Urban Forest Strategy, which states that urban green provides critical ecosystem services such as air and water filtration, shade, habitat, oxygen, carbon sequestration, and nutrient cycling - and the benefits span environmental, economic, cultural, and political domains (City of Melbourne 2012). The Urban Forest Strategy is further backed up by its companion strategy, the Urban Ecology and Biodiversity Strategy: The city as 
an ecosystem, which emphasizes even more the importance of biodiversity to the resilience of the urban environment, and lists many strategies to accomplish the city's goals (City of Melbourne 2017).

Singapore, also known as the Garden City and named by National Geographic as the world's greenest city, has been devoted to the greening of their city since their Prime Minister launched the Tree Planting Campaign more than 40 years ago. Their National Climate Change Strategy is similar to Barcelona's in that it sees GI as an important way to absorb heat, lower building temperatures and mitigate the urban heat island effect, thus saving energy for cooling. It also agrees with Melbourne that conserving biodiversity will enhance the resilience of the city to climate change pressures (Republic of Singapore 2012). Linked to their climate action plan is their Singapore Green Plan 2012 (Luen 2012) and Conserving Our Biodiversity: Singapore’s National Biodiversity Strategy and Action Plan (National Parks Board 2009), which both show Singapore's commitment to environmental sustainability and emphasize the importance of protecting their biodiversity from climate change.

Johannesburg's Climate Change Adaptation Plan identifies GI as a way to mitigate many effects of climate change in the city, such as the increased heat and flooding, as well as a way to increase water security. They also recognize the importance of adapting to climate change through creating a resilient and diverse environment (City of Johannesburg 2009). For these reasons, Johannesburg has both a GI strategy and a biodiversity strategy. The City of Joburg Biodiversity Strategy and Action Plan 2015 identifies several benefits of including healthy ecosystems in cities, such as the production of energy and water, the control of climate and waste, nutrient cycling and crop pollination, education and recreational benefits, and the "guarding against uncertainty through the maintenance of biodiversity" (City of Johannesburg 
2009). The Framework for a Green Infrastructure Planning Approach in the Gauteng CityRegion describes how GI can be used to harness the functions and services that ecosystems provide, thereby creating resilient and livable cities (Culwick 2016).

Rio de Janeiro was the first city in the world to join the Compact of Mayors, which was activated under the $\mathrm{C} 40$ Cities Climate Leadership Group, and is an alliance of cities pledging to reduce greenhouse gas emissions, enhance resilience to climate change, and track their progress. Rio's first move caused several other cities to join suit, including 15 U.S. cities committed by Barack Obama in 2015 (C40 2018). In the Climate Adaptation Strategy for the City of Rio de Janeiro, they emphasize the importance of adaptation, rather than mitigation, as a way to prepare for the changes already occurring and the future changes that are so unpredictable. This has been a recurring theme throughout all of the city strategies mentioned thus far, with biodiversity / healthy natural ecosystems being at the forefront of climate change adaptation (Nelson 2016). Nearly one half of Rio's climate action plan is devoted to GI and biodiversity, yet they do not have their own biodiversity or GI strategy. Instead, they subscribe to the National Biodiversity Strategy and Action Plan of Brazil, which emphasizes the importance of healthy ecosystems within the city for climate change adaptation (Scaramuzza 2016).

In 1993, Portland was the first U.S. city to create a local climate action plan, and they are proud of the urban forest canopy, natural areas, biodiversity, habitat corridors, and green roofs that are found throughout the community. A recent update, Portland's Climate Action Plan 2015, devotes one of its 9 chapters to "Urban Forest, Natural Systems and Carbon Sequestration", but also mentions GI briefly in "A Prosperous, Healthy, and Equitable Community" chapter and extensively in their "Climate Change Preparation" chapter. Throughout the strategy it lists trees and other vegetation as critical elements of their climate preparedness strategy because they 
reduce the amount of carbon in the atmosphere by sequestering and storing it. They say that preserving and restoring the urban forest and understory, healthy soils, and wetlands helps slow down climate change while also providing benefits such as water retention, wildlife habitats, opportunities to grow food, and public health. Furthermore, GI helps lower the air temperatures, alleviate pollution, and reduce flooding and landslides (City of Portland 2015). The Portland region also has a Regional Conservation Strategy which states that Portland's future prosperity and resilience will be determined by how well we are able to integrate our built environment with natural systems, and offers several strategies to make that happen (Intertwine 2010).

\section{Definitions of $G I$}

While many different definitions of GI exist, the EPA defines green infrastructure as using "vegetation, soils, and other elements and practices to restore some of the natural processes required to manage water and create healthier urban environments. At the city or county scale, green infrastructure is a patchwork of natural areas that provides habitat, flood protection, cleaner air, and cleaner water. At the neighborhood or site scale, stormwater management systems that mimic nature soak up and store water" (EPA 2016).

All of the cities analyzed had fairly similar ideas on the definitions of green infrastructure (see Table 2 below), many of which mention landscaped or natural vegetation in many different forms and places - providing multiple ecosystem services. Barcelona and Johannesburg emphasize the importance of a GI network, and Melbourne seems to be the only city which mentions the soil and water in regards to GI (Portland mentions the importance of soil in its Climate Action Plan, but not in its official GI definition). 
Table 2: How each city defines green infrastructure (GI) (bold = themes).

\begin{tabular}{|c|c|}
\hline City & Definition of GI \\
\hline Barcelona & $\begin{array}{l}\text { "A network of spaces with public or private agricultural or landscaped } \\
\text { natural vegetation, a multi-purpose resource providing ecological, } \\
\text { environmental, social, and economic services...enhanced further when } \\
\text { connectivity of green infrastructure is achieved" (City of Barcelona 2013, } \\
\text { p.6). }\end{array}$ \\
\hline Melbourne & $\begin{array}{l}\text { "The City of Melbourne's urban forest comprises all of the trees and other } \\
\text { vegetation - and the soil and water that supports it - within the } \\
\text { municipality. It incorporates vegetation in streets, parks, gardens, plazas, } \\
\text { campuses, river and creek embankments, wetlands, railway corridors, } \\
\text { community gardens, green walls, balconies, and roofs" (City of Melbourne } \\
2012, \text { p.9). }\end{array}$ \\
\hline Singapore & $\begin{array}{c}\text { None given (interesting as this is one of the cities that is most known for } \\
\text { their GI)... }\end{array}$ \\
\hline Johannesburg & $\begin{array}{l}\text { "The interconnected set of natural and constructed ecological systems, } \\
\text { green spaces and other landscape features. It includes planted and } \\
\text { indigenous trees, wetlands, parks, green open spaces and original grassland } \\
\text { and woodlands, as well as possible building and street level design } \\
\text { inventions that incorporate vegetation. Together these assets form an } \\
\text { infrastructure network providing services and strategic functions in the } \\
\text { same way as traditional grey infrastructure" (Culwick 2016, p.7). }\end{array}$ \\
\hline $\begin{array}{l}\text { Rio de } \\
\text { Janeiro }\end{array}$ & Not given. \\
\hline Portland & $\begin{array}{c}\text { "...green infrastructure encompasses The Intertwine itself and the } \\
\text { emerging inventory of trees, open spaces, reclaimed urban land, rain } \\
\text { gardens, eco-roofs, and other vegetated facilities that mimic natural } \\
\text { functions and provide multiple ecosystem services" (Intertwine } 2010 \text {, } \\
\text { p.91). } \\
\text { "Public or private assets - either natural resources or engineered facilities - } \\
\text { that protect, support or mimic natural systems to provide stormwater } \\
\text { management, water quality, public health and safety, open space or other } \\
\text { complementary ecosystem services. Examples include trees, ecoroofs, } \\
\text { green street facilities, wetlands, natural areas and natural waterways (City } \\
\text { of Portland } 2015, \text { p.150). }\end{array}$ \\
\hline
\end{tabular}

\section{Climate Risks Identified}

Table 3 (below) shows that cities all over the world have identified similar climate change related risks - even though they represent very different climates and locales. The risks identified by Portland were also named by many of the other 5 cities, including the urban heat island / increased heat waves (5/5), drought (4/5), floods (3/5), wildfire (2/5), and landslides 
(1/5). As coastal cities, Rio, Melbourne, Singapore, and Barcelona are all worried about either sea level rise or coastal erosion, whereas Johannesburg and Portland do not face this challenge. This could be a reason for differences in implementation strategies later on. Portland also doesn't share the same bioclimatic zone with any of the other cities, which could be another possible reason for differences.

Table 3: Climate risks each city is facing $(\mathbf{b o l d}=$ risks shared with Portland $)$

\begin{tabular}{|c|c|c|}
\hline City & Risks of each city & $\begin{array}{c}\text { Bioclimatic zone / } \\
\text { location }\end{array}$ \\
\hline Barcelona & $\begin{array}{l}\text {-urban heat island (UHI) / heat waves } \\
\text {-drought, floods, wildfires } \\
\text {-coastal erosion } \\
\text {-increase in water demand } \\
\text {-increase in energy consumption }\end{array}$ & $\begin{array}{l}\text {-mediterranean forests, } \\
\text { woodlands, and shrub } \\
\text { temperate biome } \\
\text {-coastal }\end{array}$ \\
\hline Melbourne & $\begin{array}{l}\text {-reduced rainfall and drought } \\
\text {-UHI } \\
\text {-extreme heatwave and bushfire } \\
\text {-intense rainfall and windstorm } \\
\text {-sea level rise }\end{array}$ & $\begin{array}{l}\text {-warm temperate dry } \\
\text { forest biome } \\
\text {-coastal }\end{array}$ \\
\hline Singapore & $\begin{array}{l}\text {-extreme weather events } \\
\text {-UHI } \\
\text {-changes in rainfall (more intense / } \\
\text { prolonged drought) } \\
\text {-flooding } \\
\text {-coastal erosion } \\
\text {-impacts to biodiversity }\end{array}$ & $\begin{array}{l}\text {-tropical moist forest } \\
\text { biome } \\
\text {-coastal }\end{array}$ \\
\hline Johannesburg & $\begin{array}{l}\text {-UHI / extreme heat, precipitation, } \\
\text { weather events } \\
\text {-decreased air quality, natural resources, } \\
\text { biodiversity } \\
\text {-increased occurrence of health issues } \\
\text {-infrastructure issues (storm water, water } \\
\text { supply, energy) }\end{array}$ & $\begin{array}{l}\text {-warm temperate dry } \\
\text { forest biome } \\
\text {-non-coastal }\end{array}$ \\
\hline Rio de Janeiro & $\begin{array}{l}\text {-rise in sea levels and waves } \\
\text {-landslides } \\
\text {-heat waves / UHI } \\
\text {-floods } \\
\text {-drought }\end{array}$ & $\begin{array}{l}\text {-subtropical moist forest } \\
\text { biome } \\
\text {-coastal }\end{array}$ \\
\hline Portland & $\begin{array}{l}\text {-increased temperatures (UHI) } \\
\text {-increased incidence of drought } \\
\text {-increased wildfire frequency and } \\
\text { intensity }\end{array}$ & $\begin{array}{l}\text {-warm temperate moist } \\
\text { forest biome } \\
\text {-non-coastal }\end{array}$ \\
\hline
\end{tabular}




\begin{tabular}{|l|l|l|}
$\mid \begin{array}{l}\text {-increased incidence and magnitude of } \\
\text { damaging floods, } \\
\text {-landslides }\end{array}$ & \\
\hline
\end{tabular}

\section{Mitigation/Adaptation Strategies}

Overall, Portland utilizes many of the same strategies as other cities when it comes to climate change mitigation and adaptation - there are just a few small differences. While Portland does mention increasing vegetation throughout the city, it is not as explicit as some of the other cities, who want to fill every possible gap with green and create opportunities for GI wherever possible (see Table 4). Portland also mentions monitoring and maintaining GI, but other cities specifically mentioned ecosystems and habitat function in regards to monitoring. Lastly, Portland didn't explicitly mention the idea of clustering parks with complementary ecosystems and green links as Singapore does (see Appendix A for specific strategies of each city).

There were also quite a few types of approaches that came up multiple times while analyzing the plans (see underlined in Appendix A), such as maintaining and monitoring GI, connecting and protecting GI, restoring and diversifying GI, and extending and promoting GI. All of these approaches will be important in the survey, where stakeholders will be able to select the types of GI initiatives they are implementing.

Table 4: Synergies and gaps in GI strategies in Portland vs. around the world (see Appendix A to link strategies to each city)

\begin{tabular}{|l|l|}
\hline \multicolumn{1}{|c|}{$\begin{array}{c}\text { Strategies included in Portland plans } \\
\text {-tree planting, maintenance,monitoring, and } \\
\text { preservation programs }\end{array}$} & $\begin{array}{c}\text { Strategies not included in Portland plans } \\
\text { (from other cities) }\end{array}$ \\
-manage invasive species & $\begin{array}{l}\text {-fill all gaps with green to achieve maximum } \\
\text {-restore and protect natural areas }\end{array}$ \\
-increase natural areas & $\begin{array}{l}\text {-create more planting opportunities } \\
\text {-monitor health of ecosystems }\end{array}$ \\
-expand urban forest canopy and implement & -cluster parks with complimentary ecosystems \\
-address age, diversity, and distribution of & and activities and connect with island wide \\
vegetation & -maximize rainfall interception \\
\hline
\end{tabular}


-encourage native / climate resilient species

-protect and enhance local natural resources

that provide multiple benefits

-pursue incentives and funding to accelerate

and sustain GI

-require designing with nature (eco-roof

targets)

-incorporate ecosystem service productivity

into planning / development

-enhance and protect ecosystem services -keep

streams cooler by increasing width of

vegetated areas along them

-protect and connect floodplains and other

diverse habitats that support biodiversity

-use GI to manage stormwater naturally

(protect / restore streams, wetlands and

floodplains, reduce paved surfaces)

-conserve open habitat

-consider connectivity in urban and

transportation planning

-remove barriers to habitat connectivity

-monitor and maintain GI

\section{Types of GI Solutions}

Again, Portland's plan mentions many of the same types of GI that other cities do (see

Table 5), with the exception of green walls, decks, and gardens, permeable pavement, or rain

gardens. However, just because some strategies or types of GI aren't included in Portland's

plans, doesn't mean that they are not being implemented. This is where the survey will be useful.

Table 5: Types of GI implemented in each city (bold = types shared with Portland)

\begin{tabular}{|c|l|}
\hline City & \multicolumn{1}{c|}{ Type of GI } \\
\hline Barcelona & $\begin{array}{l}\text { open natural spaces, urban forest, green roofs, walls, decks, gardens, tree } \\
\text { lined / landscaped streets / squares, vegetable gardens, parks, river area, } \\
\text { coast }\end{array}$ \\
\hline Melbourne & $\begin{array}{l}\text { tree canopy (street and open space), open green space, green walls, } \\
\text { roofs, laneways, shrubs, ground cover, grasses, soil, topography, } \\
\text { hydrology, storm water, permeability, path networks }\end{array}$ \\
\hline Singapore & $\begin{array}{l}\text { green corridors, parks, vertical greening / rooftop gardens, open green } \\
\text { spaces, all vegetation, waterways, forest canopy }\end{array}$ \\
\hline Johannesburg & $\begin{array}{l}\text { street trees, lawns / parks, urban forest, cultivated land, wetlands, } \\
\text { streams, lakes / sea, corridors, bioswales, permeable pavement, }\end{array}$ \\
\hline
\end{tabular}




\begin{tabular}{|c|l|} 
& $\begin{array}{l}\text { stormwater ponds, bio-retention structures, rain gardens, green streets, } \\
\text { parking, roofs }\end{array}$ \\
\hline Rio de Janeiro & $\begin{array}{l}\text { green streets, urban forest canopy, permeable pavement, rain and bio- } \\
\text { ditchers, green corridors }\end{array}$ \\
\hline Portland & $\begin{array}{l}\text { eco-roofs, trees, plants, soil, urban forest canopy, water bodies, parks, } \\
\text { flood plains, green corridors, green streets, bioswales }\end{array}$ \\
\hline
\end{tabular}

\section{Portland's GI so far}

The City of Portland has already been hard at work on the implementation of GI, with over 390 ecoroofs covering nearly 20 acres of rooftop - managing millions of gallons of stormwater every year, they have planted over three million new trees and shrubs since 1996, and treated and managed invasive species over 7,400 acres of parks, roadsides, and private property as of 2015 (City of Portland 2015). According to the City of Portland's 2017 Climate Action Plan Progress Report, they have continued planting trees and other vegetation, removing invasive species, creating new habitat, and improving watershed health. This has all been done through extensive community involvement, with over 50 educational workshops held on the maintenance and preservation of trees throughout Portland neighborhoods. Their goals through 2030 are to continue increasing GI and natural areas in order to sequester carbon, to reduce impervious areas by 600 acres, and to expand the urban forest canopy to cover at least one third of the city (City of Portland 2017).

\section{Survey}

The survey was designed to include several components which will tell us what organizations in the Portland area are doing in regards to GI implementation and why. It will also tell us if and how they are utilizing Portland's Climate Action Plan, Regional Conservation Strategy, or some other climate or GI related plan, and shed some light on issues in Portland 
related to climate change and GI. Figure 1 shows a few sample survey questions that were used to provide insight into the concepts we were interested in learning more about from the conservation community in Portland (see Appendix B for the full survey).

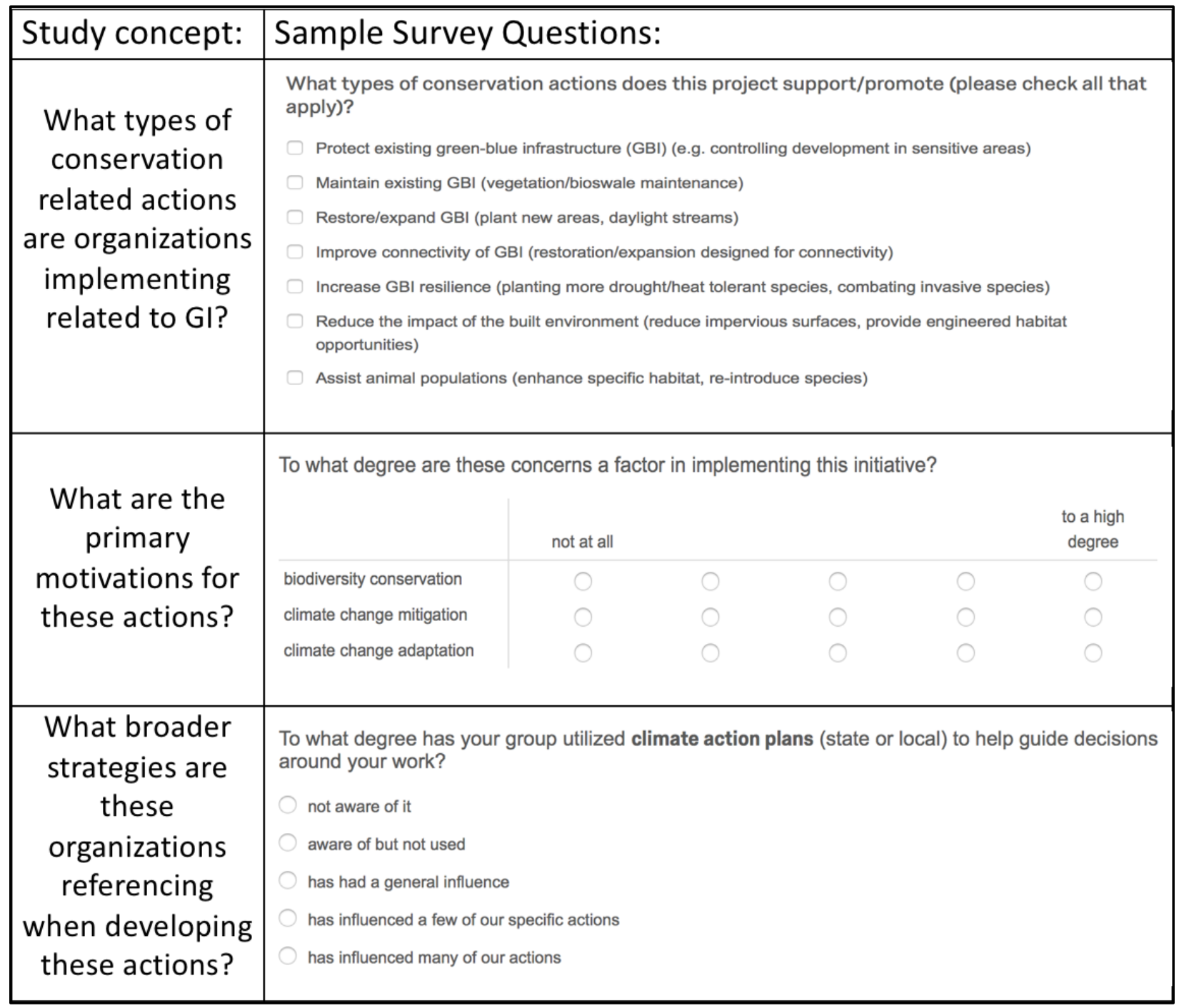

Figure 1: concepts we were interested in learning more about from conservation organizations and sample survey questions to answer those questions.

The survey starts by letting stakeholders enter a specific initiative they are working on in Portland, which will tell us what types of GI their initiative implements. From there, they can enter the names of the plans that influenced their initiative and select the types of actions their 
initiative promotes (from the themes found during document analysis - protect, maintain, restore, etc). Questions at the end of the survey will provide insight into the types of initiatives stakeholders would like to be working on, but are not able to due to some limitations. This could tell us why Portland might not be implementing the same strategies as cities around the world, and hopefully facilitate discussion about how we can get past these limitations to incorporate maximum GI into our landscape.

\section{Discussion and Conclusion}

It has become increasingly clear that it is up to cities to combat climate change, as a large proportion of the global population resides in cities and exerts huge demands on our natural environment. Researchers from fields ranging from civil engineering, environmental health, and environmental and energy policy have emphasized the importance of local climate action plans as an opportunity to engage vast segments of the global population and mitigate the impacts of climate change in large spatial areas (Ramaswami 2008), as well as a way to test the political responses to innovative policies and provide opportunities for policy experimentation (Lutsey 2008), and to help countries meet their commitments within international climate agreements (Betsill 2001). Local policies can also be used as a source of public and corporate education, and as a source of pressure and encouragement to national and international policy efforts (Kosloff 2004). Environmental and energy policy makers in Portland (Kosloff et al.) emphasize the importance of encouraging and evaluating state and local policies in the context of the overall scale of interventions that are needed to address climate change. This study has contributed to the literature by evaluating a selection of these local climate policies that are so important to climate change mitigation and determining how they compare to one another, and the future results of 
the survey on GI implementation will further contribute to the literature by determining whether these local strategies are actually being utilized by their audience and whether they are effective.

Climate action strategies of cities all over the world have emphasized the importance of GI as a way to mitigate and adapt to the effects of climate change, and have done so throughout many different areas of each strategy - whether it be related to public health, climate conscious city planning, heat prevention, or climate change mitigation and adaptation in general. In the case of Barcelona's Climate Plan 2018 and Melbourne's City of Melbourne Climate Change Adaptation Strategy, GI strategies were mentioned right away as the city discussed its ongoing work related to climate change mitigation - whereas in Singapore, Johannesburg, and Rio de Janeiro it was mentioned as they discussed potential impacts of climate change on biodiversity and how that was being handled so far. Portland's Climate Action Plan 2015 is the only climate plan which does not reference its accompanying biodiversity or GI strategy (the Regional Conservation Strategy), however, the survey will be able to give us insight on whether or not that strategy is being utilized.

Further analysis of these documents showed that Portland has much in common with these other climate-leading cities around the world, such as the potential risks faced, especially the risks of increased heat waves, the urban heat island, drought, and floods. Coastal cities, such as Rio, Melbourne, Singapore, and Barcelona, faced the additional risks of sea level rise and coastal erosion - which are not major threats to Portland. Despite these differences, these cities share more risks than not, and it is clear that they would all benefit from sharing strategies to combat these similar risks.

Along with other cities, Portland is dedicated to actions such as increasing tree canopy and natural areas, managing invasive species as well as diversifying species in their GI, 
protecting natural areas and ecosystem services, monitoring and maintaining their GI, and connecting diverse habitats and vegetated areas throughout the city. However, Portland is not as explicit as the other cities when it come to filling every possible gap with green, or when it comes to creating as many opportunities for green infrastructure throughout the city as possible. Furthermore, while Portland did mention monitoring and maintaining GI, they were not as specific as other cities, who specifically mentioned ecosystems and habitat function in regards to monitoring. These actions may be a part of their overall goal, they are just not emphasized in their plans as much as other strategies.

When it comes to types of GI, Portland considered a lot of the same ones as the other cities throughout the landscape. These included ecoroofs, bioswales, trees, diverse plants, soil, urban forest canopy, water bodies, floodplains, parks, green corridors, and green streets. While this may seem like a lot, Portland's plan did not include as many types of GI as Melbourne or Johannesburg's strategies, such as permeable pavement, open green space, green walls, or hydrology. These differences could be due to the different bioclimatic zones that the areas are located in, whether the area is coastal or non coastal, or the relative importance of risks faced.

Overall, this study showed that these city strategies have a lot in common in regards to various aspects of climate change adaptation and mitigation. Each city emphasized either green infrastructure, biodiversity, the city as an ecosystem, or all three in various chapters of their climate action strategies. They all included similar / closely related ideas in their definitions of GI, such as the importance of ecosystem services and diverse vegetation - which are reflected in the types of strategies each city implements throughout the city as well as in the types of GI utilized in those strategies. However, the strategies emphasized / not emphasized in these plans may not correspond to initiatives that are / aren't actually being implemented in Portland - which 
is why the survey will be necessary. With the survey on GI initiatives, it will be revealed whether or not Portland is actually playing its part in the fight against climate change - regardless of what the strategies say. It will also answer questions that conservationists in Portland have about what organizations in Portland are doing about climate change. It will tell us how they are doing it, why they are doing it (are they implementing these strategies because of plans that influenced them, or do they not even know these plans exist?), and why they might NOT be doing it. With all of this information, we can hold a regional forum on climate change and GI in Portland, which will inform organizations of what is being done for climate challenges in Portland, what is not being done enough, and innovative ways that these challenges can be adapted to or mitigated. This will hopefully facilitate even more collaboration, knowledge sharing, and increased climate action. 


\section{References}

Betsill, M. M. (2001). Mitigating Climate Change in US Cities: opportunities and obstacles. Local Environment, 6(4), 393-406. Retrieved from http://citeseerx.ist.psu.edu/viewdoc/download?doi=10.1.1.177.7251\&rep=rep1\&type=pdf

C40 Cities Climate Leadership Group. (2018). http://www.c40.org/cities

Callery, S. (2017). Global Climate Change (H. Shaftel, Ed.). Retrieved from https://climate.nasa.gov/

City of Barcelona. (2011). The energy, climate change and air quality plan of Barcelona (PECQ 2011-2020). Barcelona the Environment.

City of Barcelona (2013). Barcelona, a city committed to combating climate change. Environmental Report. Retrieved from https://bcnroc.ajuntament.barcelona.cat/jspui/bitstream/11703/83511/1/informe ambienta 1 BCN 2013 ENG resum.pdf.

City of Barcelona. (2013). Barcelona green infrastructure and biodiversity plan 2020. City of Barcelona, Retrieved from https://climate-adapt.eea.europa.eu/metadata/casestudies/barcelona-trees-tempering-the-mediterranean-city-climate/11302639.pdf

City of Barcelona. (2018). Climate Plan 2018-2030. City of Barcelona, Retrieved from http://lameva.barcelona.cat/barcelona-pel-

clima/sites/default/files/documents/eng_climate_plan_def.pdf

City of Johannesburg. (2009). City of Joburg Biodiversity Strategy and Action Plan. City of Joburg: Department of Environmental Management. Retrieved from https://www.cbd.int/doc/nbsap/sbsap/za-sbsap-johannesburg-en.pdf

City of Johannesburg. (2009). Climate Change Adaptation Plan. City of Joburg. Retrieved from https://www.preventionweb.net/files/38589_38507climatechangeadaptationplancit.pdf

City of Melbourne (2008). City of Melbourne Climate Change Adaptation Strategy. Australian Government Department of Climate Change. Retrieved from http://www.melbourne.vic.gov.au/SiteCollectionDocuments/climate-change-adaptationstrategy.pdf

City of Melbourne (2012). Urban Forest Strategy: Making a great city greener 2012-2032. City of Melbourne. Retrieved from http://www.melbourne.vic.gov.au/SiteCollectionDocuments/urban-forest-strategy.pdf

City of Melbourne. (2017). Urban Ecology and Biodiversity Strategy: The City as an Ecosystem. Retrieved from https://participate.melbourne.vic.gov.au/application/files/4214/6524/9371/Draft_Urban_E cology_and_Biodiversity_Strategy.pdf

City of Portland (2015). Climate Action Plan: Local Strategies to Address Climate Change. Portland, Oregon. Retrieved from https://www.portlandoregon.gov/bps/article/531984.

City of Portland (2017). City of Portland and Multnomah County Climate Action Plan Progress Report. Portland, Oregon. Retrieved from https://www.portlandoregon.gov/bps/article/636700 
Culwick, C., Bobbins, K. (2016). A Framework for a Green Infrastructure Planning Approach in the Gauteng-City Region. Gauteng-City Region Observatory. Retrieved from http://wiredspace.wits.ac.za/bitstream/handle/10539/23595/_GCRO_Green\%20Assets_R eport_Digital\%20version_\%20book.pdf?sequence=1\&isAllowed=y

EPA. (2016). Green Infrastructure for Climate Resiliency. Retrieved from https://www.epa.gov/green-infrastructure/green-infrastructure-climate-resiliency

European Commission. (n.d.). Green Infrastructure and Climate Adaptation. Retrieved from http://ec.europa.eu/environment/nature/ecosystems/pdf/Green\%20Infrastructure/GI_clim ate adaptation.pdf

Gill, S. E., Handley, J. F., Ennos, A. R., \& Pauleit, S. (2007). Adapting Cities for Climate Change: The Role of the Green Infrastructure. Built Environment, 33(1), 115-133. Retrieved from http://urbanspace.rec.org/files/Article_Gill_Adapting_Cities_for_CC.pdf

Intertwine Alliance (2010). Regional Conservation Strategy for the Greater Portland-Vancouver Region. Portland, Oregon, 35-48. Retrieved December 02, 2017 from http://www.theintertwine.org/alliance/intertwine-focus-areas/conservation

IPCC, 2014: Climate Change 2014: Synthesis Report. Contribution of Working Groups I, II and III to the Fifth Assessment Report of the Intergovernmental Panel on Climate Change [Core Writing Team, R.K. Pachauri and L.A. Meyer (eds.)]. IPCC, Geneva, Switzerland, $151 \mathrm{pp}$. Retrieved from http:/www.ipcc.ch/pdf/assessmentreport/ar5/syr/SYR AR5 FINAL full wcover.pdf

Kosloff, L. H., Trexler, M. C., \& Nelson, H. (2004). Outcome-Oriented Leadership: How State and Local Climate Change Strategies Can Most Effectively Contribute to Global Warming Mitigation. Widener Law Journal, 14, 173-204.

Leiserowitz, A., Maibach, E., Roser-Renouf, C., Rosenthal, S., \& Cutler, M. (2017). Climate change in the American mind: May 2017. Yale University and George Mason University. New Haven, CT: Yale Program on Climate Change Communication.

Luen, F.S. (2012). The Singapore Green Plan 2012. Ministry of the Environment and Water Resources, Singapore. Retrieved from https://www.mewr.gov.sg/docs/defaultsource/default-document-library/grab-our-research/sgp2012 2006edition new.pdf

Lutsey, N., \& Sperling, D. (2007). America's bottom-up climate change mitigation policy. Energy Policy, 36, 673-685. Retrieved from https://cloudfront.escholarship.org/dist/prd/content/qt8jj755d4/qt8jj755d4.pdf

National Parks Board, Singapore. (2009). Conserving our Biodiversity: Singapore's National Biodiversity Strategy and Action Plan. National Parks Board. Retrieved from https://www.nparks.gov.sg/biodiversity/our-national-plan-for-conservation//media/nparks-real-content/biodiversity/national-plan/nbsap 2009.pdf

Nelson, F. (2016). Climate Change Adaptation Strategy for the City of Rio de Janeiro. Retrieved from http://centroclima.coppe.ufrj.br/images/Noticias/documentos/estrategia-ing.pdf

Ramaswami, A., Hillman, T., Janson, B., Reiner, M., \& Thomas, G. (2008). A DemandCentered, Hybrid Life-Cycle Methodology for City-Scale Greenhouse Gas Inventories. Environmental Science Technology, 42(17), 6455-6461. Retrieved from https://pubs.acs.org/doi/pdf/10.1021/es702992q 
Republic of Singapore. (2012). National Climate Change Strategy. Climate Change \& Singapore: Challenges. Opportunities. Partnerships. Retrieved from http://www.nea.gov.sg/docs/default-source/energy-waste/climate-change/nccs-2012.pdf

Scaramuzza, C. (2016). National Biodiversity Strategy and Action Plan. Ministry of the Environment. Retrieved from https://www.cbd.int/doc/world/br/br-nbsap-v3-en.p

The Impact of Climate Change on Cities. (N.d.). Cities and Climate Change: An Urgent Agenda, Retrieved from https://siteresources.worldbank.org/INTUWM/Resources/3402321205330656272/4768406-1291309208465/PartII.pdf

UERC (2017). 15th Annual Urban Ecology and Conservation Symposium. Retrieved from https://docs.google.com/viewer?a=v\&pid=sites\&srcid=ZGVmYXVsdGRvbWFpbnx1ZX JjcG9ydGxhbmR8Z3g6MmNhZWFkOWZjY2M2MmY5NQ

Weible, C., \& Elgin, D. (2013). Contrasting Capacities From City to International Levels of Government in Addressing Climate and Energy Issues. Cityscape: A Journal of Policy Development and Research, 15(1), 163-180. Retrieved from https://www.huduser.gov/portal/periodicals/cityscpe/vol15num1/Cityscape_March2013_ cont_cap.pdf

Wilby, R. L. (2007). A Review of Climate Change Impacts on the Built Environment. Built Environment, 33(1), 31-45. Retrieved from

https://d3dqsm2futmewz.cloudfront.net/docs/ugec/other-conferences/wilby-paper.pdf 


\section{Appendix A: table of strategies each city has in place to address climate}

\section{challenges and themes found}

\begin{tabular}{|c|c|}
\hline \multicolumn{2}{|c|}{$\begin{array}{c}\text { Strategies each city has in place to address climate challenges }(\mathbf{b o l d}=\text { strategy shared with } \\
\text { Portland, underlined = themes })\end{array}$} \\
\hline City & Strategy \\
\hline Barcelona & $\begin{array}{l}\text {-increase nature in city } \\
\text {-preserve habitats and species } \\
\text {-create a mosaic of habitats } \\
\text {-diversify species } \\
\text {-design with pro-ecological services in mind } \\
\text {-maintain GI } \\
\text {-preserve street trees } \\
\text {-fill all gaps with green to achieve maximum GI } \\
\text {-ensure connectivity of GI } \\
\text {-enhance habitat function of GI } \\
\text {-strengthen conservation of GI networks }\end{array}$ \\
\hline Melbourne & $\begin{array}{l}\text {-increase tree canopy cover } \\
\text {-increase urban forest diversity (species, age, special) } \\
\text {-improve vegetation health by improving soil moisture / water quality } \\
\text {-protect / enhance level of biodiversity that contributes to healthy } \\
\text { ecosystems } \\
\text {-manage existing landscape / adapt new ones } \\
\text {-create more planting opportunities } \\
\text {-enhance ecological connectivity }\end{array}$ \\
\hline Singapore & $\begin{array}{l}\text {-conserve and enhance biodiversity at the genetic, species, and ecosystem } \\
\text { levels } \\
\text {-rehabilitate degraded areas } \\
\text {-extend green corridors } \\
\text {-integrate natural systems into parks } \\
\text {-design with biodiversity in mind } \\
\text {-monitor health of ecosystems } \\
\text {-cluster parks with complimentary ecosystems and activities and connect } \\
\text { with island wide green links } \\
\text {-promote international collaboration } \\
\text {-rehabilitate, enhance, and manage ecosystems } \\
\text {-build and extend green spaces } \\
\text {-plant more suitable species for environment }\end{array}$ \\
\hline Johannesburg & $\begin{array}{l}\text {-protect green open spaces and sensitive natural areas (enhance) } \\
\text {-develop / upgrade parks } \\
\text {-install green roofs } \\
\text {-rehabilitate rivers / ecosystems } \\
\text {-increase tree and leaf canopy }\end{array}$ \\
\hline
\end{tabular}




\begin{tabular}{|c|c|}
\hline & $\begin{array}{l}\text {-maximize rainfall interception } \\
\text {-increase green streets } \\
\text {-increase opportunities for innovative land use } \\
\text {-increase GI networks through planter boxes, vegetated island, and green } \\
\text { roofs } \\
\text {-improve storm water and flood management }\end{array}$ \\
\hline Rio de Janeiro & $\begin{array}{l}\text {-expand and enforce the official protection of natural ecosystems } \\
\text {-recover, protect, manage, and extend green areas with native vegetation } \\
\text {-use species best suited to climate } \\
\text {-promote and strengthen reforestation actions } \\
\text {-incorporate future climate lens into planning } \\
\text {-promote open multifunctional spaces } \\
\text {-integrate water sensitive urban design } \\
\text {-monitor land use and cover } \\
\text {-increase connectivity } \\
\text {-increase sustainable use of biodiversity } \\
\text {-manage invasive species }\end{array}$ \\
\hline Portland & $\begin{array}{l}\text {-tree planting, maintenance, and preservation programs } \\
\text {-manage invasive species } \\
\text {-restore and protect natural areas } \\
\text {-increase natural areas } \\
\text {-expand urban forest canopy and implement targets } \\
\text {-address age, diversity, and distribution of vegetation } \\
\text {-encourage native / climate resilient species } \\
\text {-protect and enhance local natural resources that provide multiple benefits } \\
\text {-pursue incentives and funding to accelerate and sustain GI } \\
\text {-require designing with nature (eco-roof targets) } \\
\text {-incorporate ecosystem service productivity into planning / development } \\
\text {-enhance and protect ecosystem services } \\
\text {-keep streams cooler by increasing width of vegetated areas along them } \\
\text {-protect and connect floodplains and other diverse habitats that support } \\
\text { biodiversity } \\
\text {-use GI to manage stormwater naturally (protect / restore streams, } \\
\text { wetlands and floodplains, reduce paved surfaces) } \\
\text {-conserve open habitat } \\
\text {-consider connectivity in urban and transportation planning } \\
\text {-remove barriers to habitat connectivity } \\
\text {-monitor and maintain GI }\end{array}$ \\
\hline
\end{tabular}

Appendix B: the survey 


\section{UERC Climate Change Survey}

\section{Start of Block: Name-Org}

Q1.1 We would like to ask for your participation in a survey about green-blue infrastructure activities and climate change in the Portland-Vancouver region. Here we use the concept of green-blue infrastructure to broadly capture the use of more nature-based solutions to urban challenges. This effort stems from a lunch discussion on climate change at the Urban Ecosystem Research Consortium symposium (UERC, Feb 6, 2017), which identified interest in exchanging information on this topic.

Q1.2 Name (note we will ask about your desired level of confidentiality at the end of the survey)

Q1.3 Organization

Q1.4 Sub-organizational unit (if applicable) 
Q2.1 This first part of the survey is oriented around the major initiatives/projects/actions that your organization carries out related to green/blue infrastructure. For each major initiative, please answer the following questions (if you have many, perhaps choose 1-3).

\section{Display This Question:}

\section{If Loop all: Is there another initiative you would like to include? != No}

Q2.2 What is the title of the initiative?

\section{Display This Question:}

\section{If Loop all: Is there another initiative you would like to include? != No}

Q2.3 List any key partners with whom you are collaborating on this strategy (one per line).

\section{Display This Question:}

\section{If Loop all: Is there another initiative you would like to include? != No}

Q2.4 To what degree are these concerns a factor in implementing this initiative?

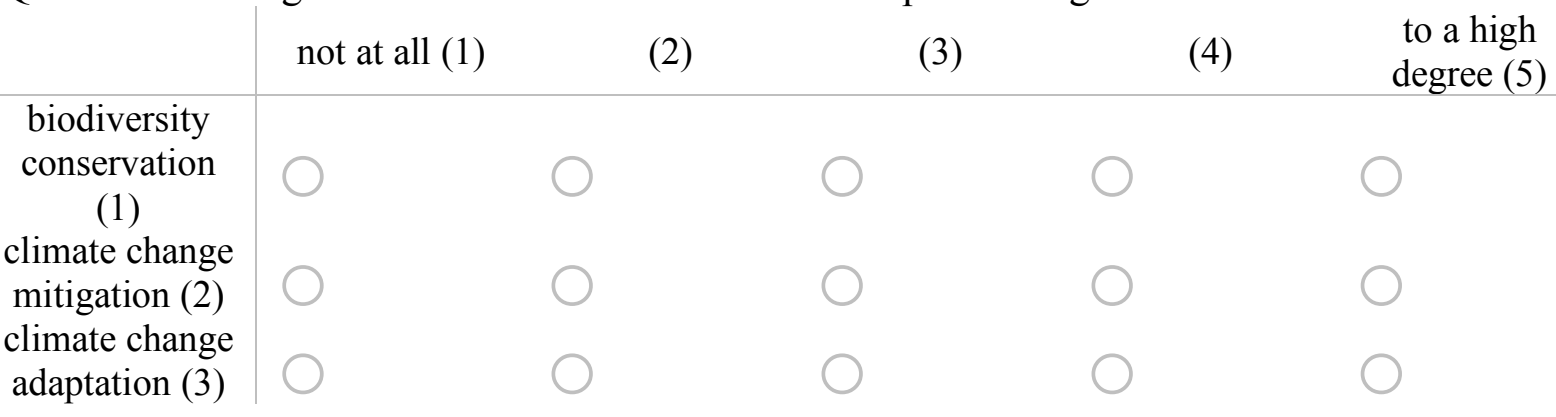




\section{Display This Question:}

If Loop all: Is there another initiative you would like to include? != No

Q2.5 Please list any other major reasons for implementing this initiative:

\section{Display This Question:}

If Loop all: Is there another initiative you would like to include? != No

Q2.6 Was this initiative influenced by any broader plans or strategies? (please list, one per line) 
Q2.7 What types of approaches are you using in this initiative? (please check all that apply)?

$\square$ On the ground management (1)

Technical assistance (2)

Communication / awareness (3)

Community engagement (4)

Providing incentives (5)

Advocacy / lobbying (6)

Planning / policy / regulation (7)

Research (8)

Monitoring (9) 
Q2.8 What types of conservation actions does this project support/promote (please check all that apply)?

Protect existing green-blue infrastructure (GBI) (e.g. controlling development in sensitive areas) (1)

Maintain existing GBI (vegetation/bioswale maintenance) (2)

Restore/expand GBI (plant new areas, daylight streams) (3)

Improve connectivity of GBI (restoration/expansion designed for connectivity) (4)

Increase GBI resilience (planting more drought/heat tolerant species, combating invasive species) (5)

Reduce the impact of the built environment (reduce impervious surfaces, provide engineered habitat opportunities) (6)

Assist animal populations (enhance specific habitat, re-introduce species) (7) 
Q2.9 Is the project specifically trying to address any of these climate change-related risks (check all that apply)?

Increased incidents of short-term drought (1)

Reduced air quality (2)

Increase in average annual air temperatures and likelihood of extreme heat events (3)

Changes in hydrology, water supply, and stream flows (4)

Reduced water quality (5)

Changes in wetland ecosystems (6)

Increase in breeding grounds for water-borne diseases (7)

\section{Display This Question:}

If Loop all: Is there another initiative you would like to include? != No

Q2.10 In what general geographic areas is your project active?

Oregon-City of Portland (1)

Oregon metro east (Gresham, Troutdate, Damascus) (2)

Oregon metro west (Forest Park, Beaverton, Hillsboro) (3)

Oregon metro south (Tigard, Tualatin, Lake Oswego, Wilsonville) (4)

Washington-City of Vancouver (5)

Washington metro east (Camas) (6)

Washington metro northwest (Battleground, Ridgefield) (7) 


\section{Display This Question:}

If Loop all: Is there another initiative you would like to include? != No

Q2.11 Is there another initiative you would like to include?

Yes (1)

No (2)

\section{End of Block: Project questions}

\section{Start of Block: General questions}

Q3.1 To what degree has your group utilized the Regional Conservation Strategy climate change chapter and matrix to help guide decisions around your work?

not aware of it (1)

aware of but not used (2)

has had a general influence (3)

has influenced a few of our specific actions (4)

has influenced many of our actions (5)

Q3.2 To what degree has your group utilized climate action plans (state or local) to help guide decisions around your work?

not aware of it (1)

aware of but not used (2)

has had a general influence (3)

has influenced a few of our specific actions (4)

has influenced many of our actions (5) 
Q3.3 Do you have some general comments on the utility of the conservation or climate action plans for your work?

Q3.5 What do you think are some of the most important challenges/decisions being made related to green/blue infrastructure in the Portland-Vancouver region (and which organizations are the primary decision makers)?

Q3.6 Are there any projects your organization would like to be working on, but are not able to? What are your limitations? 
Q3.7 How interested would you be in attending a half-day regional forum on green/blue infrastructure and climate change?

Extremely likely (1)

Somewhat likely (2)

Neither likely nor unlikely (3)

Somewhat unlikely (4)

Extremely unlikely (5)

Q3.8 Are there any innovative projects/topics you might like to share in such a forum?

Q3.9 Are there any projects/topics you might like to hear about in such a forum? 
Q3.10 What level of confidentiality would you like for your answers to this survey?

Anonymous (your name will not be released beyond the immediate research team) (1)

Confidential (your name may be released but will not be associated with any of your responses) (2)

Open (your name may be shared and associated with your responses) (3) 